BIOKEMISTRI 18(1):25-30 (June 2006)

Available online at http://www.bioline.org.br/bk

and at http://www.ajol.info/journals/biokem

Printed in Nigeria



OVigerian Society for O̊xperimental \&iology

\title{
Changes in chemical composition and bioassay assessment of nutritional potentials of almond fruit waste as an alternative feedstuff for livestock
}

\author{
Azor A. ANNONGU ${ }^{1 *}$, Niyi J. OGUNDUN ${ }^{2}$, Kolade J. JOSEPH ${ }^{1}$ and Veronica AWOPETU ${ }^{1}$ \\ ${ }^{I}$ Division of Nutritional Biochemistry, Department of Animal Production, PMB 1515 University \\ of Ilorin, Ilorin, Nigeria \\ ${ }^{2}$ Federal College of Wildife Management, Forestry Research Institute of Nigeria, New Bussa, \\ Nigeria
}

Received March 20, 2005

MS/No BKM/2005/015, () 2006 Nigerian Society for Experimental Biology. All rights reserved.

\begin{abstract}
Changes in chemical composition upon processing and bioassay assessment of nutritional potentials of almond fruit waste as an alternative feedstuff were conducted using day-oldcockerels. Proximate analyses revealed that AFW contained valuable nutrients, carbohydrate/dry matter, protein, fat, fiber, mineral matter (ash). The concentration of some of these nutrients increased as the raw AFW was treated. The raw AFW gave on analysis quantitatively high concentrations of the chemical compounds, tannins, hydrocyanides, phytic acid and other unquantified chemical compounds like oxalates assessed qualitatively. Subjecting raw AFW to lactic fermentation and enzymes treatments reduced the levels of the phytochemicals. Bioassay of the treated and untreated AFW using day-old cockerels and considering performance parameters showed that treated AFW improved feed intake, body weight gain and feed conversion ratio even better than the results obtained on these indices on the reference diet ( $p$ 0.05). Untreated AFW elicited misperformance and high mortality of the test birds. It was concluded that the nutritional value of AFW, if could be used as an alternative feedstuff for animals, must be given adequate treatments.
\end{abstract}

Keywords: Almond fruit waste, nutritional potentials, chemical compounds, cockerels.

*Author to whom correspondence should be addressed. E-mail: azorannongu@ yahoo.com , Tel: 08038472754 


\section{INTRODUCTION}

Almond tree, botanically known as Terminalia catappa tree, originated from tropical Asia, India, the Malay Peninsula, Taiwan, Burma ${ }^{1}$ though thrives well in other tropical regions of the world including Nigeria. The most common species, Prunus amygdalus, has two varieties: $P$. delcis var dulas and $P$. delcis var mara which are the sweet and the bitter varieties respectively. Prunus delcis var dulas is the source of edible almond nuts while Prunus delcis var mara is grown for almond oil used for flavoring after the elimination of prussic acid The world production of almond fruits stands at 0,7 million tones and Nigeria produces 0.1 million tones annually. After the removal of the edible almond nuts used raw, in confectionaries, puddings or for oil extraction, the exocarp is discarded as waste. Initial works ${ }^{3,4}$ showed that almond fruits contained valuable nutrients but their value is limited due to the presence of phytochemical compounds capable of inducing adverse effects in fed animals. These authors observed that the presence of the anti-nutritional factors may limit the utilization of the nutrients in the fruit when used as feed or by-product by livestock. However, with emphasis on sourcing for alternative feedstuffs for feeding commercial farm animals to avoid competition between man and his animals for the available limited orthodox feedstuffs in developing and underdeveloped countries of the world, no feedstuff can be regarded as a waste, especially if such a feedstuff can be improved upon to be a useful substitute to the conventional one. It is for this reason that the present experiment in view aims at evaluating the chemical compounds and proximate composition of almond fruit exocarp discarded as waste and conducting a bioassay of the waste using poultry as test animal models to access its nutritional potential.

Evaluation of the chemical properties and nutritional potentials of a novel feedstuff like almond fruit waste (AFW) is aimed at elucidating its inherent chemical compounds and nutrients composition for the purpose of putting it to an economic use. In this case, almond fruit waste, a material considered as an unconventional feedstuff will be investigated into as a source of feedstuff for animals.

\section{MATERIALS AND METHODS}

Ripened almond fruits were collected from the almond trees around the University of Ilorin premises. The fruits were sun-dried and split open manually to obtain the wastes (exocarp). The waste was pounded to a fine meal using mortar and pestle. A sample of the raw meal was taken for analysis. Three kilograms of the meal was subjected to lactic fermentation following the procedures described by Annongu et al..$^{5}$. The $3 \mathrm{~kg}$ of the fermented AFW meal was divided into three equal parts of $1 \mathrm{~kg}$ each. To one part was added the enzyme, Nutrase xyla (NX), to another Rozaxyme $-\mathrm{G}$ (R-G) and to the other a combination of the enzymes, Multiple enzymes (ME). The enzymes were purchased from Nutrex, a commercial enzyme producing company based in Belgium. The recommended inclusion level for the enzymes was $100 \mathrm{~g} /$ tonne of feed. The enzyme treated AFW meal was incubated under solid state for 7-days at a temperature of $28 \pm 1^{\circ} \mathrm{C}$. At the end of the one week incubation, samples were taken, sun-dried and stored for subsequent analysis.

\section{Diets formulation and use of test animal models}

Five iso-energy and iso-nitrogenous diets were formulated $(2800 \mathrm{kcal} / \mathrm{kg}$ and $22 \%$ protein). The reference/control diet was made of the following ingredients: maize, soybeans, DL-methionine, mineral-vitamin premix, salt, bone meal and oyster shells, while the other four diets had maize replaced by $60 \%$ untreated AFW meal, treated AFW meal supplemented with Nutrase xyla (NX), Roxazyme -G (RG) and Multiple enzymes (ME). 120-cockerels (Olympiad breed) at day old obtained from FIDAN, a commercial poultry company based in Lagos, Nigeria, were used for the experiment. They were distributed randomly to the five dietary treatments and offered feed and water ad libitum for a period of 28-days. In the course of the feeding trial, data was recorded on feed intake, weight gain, feed efficiency and mortality.

\section{Chemical analysis}

The proximate composition of the raw, fermented and enzyme treated AFW meal was carried out according to the methods of $\mathrm{AOAC}^{6}$. Samples were analyzed for dry matter, crude 
protein, fiber, ether extract, mineral matter (ash) and nitrogen free extract, NFE was obtained by difference. Fiber fractions analyses was conducted on the raw, treated and enzyme supplemented AFW meal for acid detergent fiber (ADF), neutral detergent fiber (NDF), neutral detergent soluble (NDS), acid detergent lignin (ADL) following the procedures outlined by Goering and Van Soest ${ }^{7}$. Tannins were determined as described by $\mathrm{Jolyn}^{8}$ while hydrocyanide content was determined according to the methods of $\mathrm{AOAC}^{6}$. Determination of phytate was carried out following the procedures of Wheeler and Ferrel ${ }^{9}$.

\section{Statistics}

Data collected on chemical and proximate compositions were analyzed by simple descriptive statistics while that on performance characteristics of birds following ingestion of treated and untreated AFW meal based diets were analyzed using the model for a completely randomized design ${ }^{10}$. Where significant differences were obtained between treatment means, the means were further subjected to Duncan multiple range test ${ }^{11}$.

\section{RESULTS}

Table 1 presents data on the proximate analysis of raw, fermented and enzyme supplemented AFW meal. The analysis showed that AFW contained valuable nutrients namely protein, fat, fiber, mineral matter, high dry matter content. Treatments increased the content of some nutrients in AFW in the order $\mathrm{ME}>\mathrm{RG}>\mathrm{NX}>$ fermentation.

Fiber fractions analysis based on NDF, NDS, ADF and ADL are shown in Table 2. The fiber fractions appeared to have significantly reduced in value as a result of treatments. The reduction followed a reverse pattern similar to the result obtained on proximate analysis in that the highest reduction was recorded on multiple enzyme treatment followed by R-G, NX and fermentation. Result on analysis of some chemical compounds in AFW (Table 3) followed a trend similar to that obtained on

Table 1: Analyzed nutrients composition of the experimental diets (\%)

\begin{tabular}{l|llllll}
\hline & \multicolumn{5}{c}{ Nutrients } \\
Samples & Crude protein & Crude fat & Crude fiber & Total ash & Dry matter \\
\hline Raw AFW & $4.16 \pm 0.02$ & $4.00 \pm 0.5$ & $27.50 \pm 0.3$ & $6.75 \pm 0.03$ & $88.16 \pm 0.6$ \\
Fermented AFW & $4.40 \pm 0.05$ & $4.20 \pm 0.1$ & $50.00 \pm 0.8$ & $6.45 \pm 0.02$ & $90.42 \pm 0.7$ \\
AFW + NX & $5.00 \pm 0.13$ & $3.70 \pm 0.06$ & $49.50 \pm 0.5$ & $5.90 \pm 0.05$ & $88.92 \pm 0.53$ \\
AFW + R-G & $5.47 \pm 0.04$ & $3.80 \pm 0.03$ & $48.50 \pm 0.17$ & $6.80 \pm 0.10$ & $90.80 \pm 0.71$ \\
AFW + ME & $6.34 \pm 0.02$ & $3.90 \pm 0.05$ & $47.40 \pm 0.32$ & $6.50 \pm 0.07$ & $90.50 \pm 0.15$ \\
\hline
\end{tabular}

Table 2: Fibre fractions analysis of raw, fermented and enzyme treated AFW (\%)

\begin{tabular}{l|lccl}
\hline \multirow{2}{*}{ Samples } & \multicolumn{4}{c}{ Fibre fractions } \\
\hline Raw AFW meal & $22.20 \pm 0.09$ & $89.00 \pm 0.25$ & $48.20 \pm 0.80$ & $12.10 \pm 0.21$ \\
Fermented AFW meal & $16.70 \pm 0.36$ & $87.40 \pm 0.32$ & $47.40 \pm 0.01$ & $7.90 \pm 0.1$ \\
AFW meal + NX & $15.00 \pm 0.25$ & $86.40 \pm 0.38$ & $46.00 \pm 0.32$ & $6.90 \pm 0.30$ \\
AFW meal + R-G & $12.60 \pm 0.31$ & $84.40 \pm 0.58$ & $43.00 \pm 0.15$ & $6.80 \pm 0.05$ \\
AFW meal + ME & $10.90 \pm 0.20$ & $83.30 \pm 0.66$ & $40.80 \pm 0.46$ & $5.30 \pm 0.18$ \\
\hline
\end{tabular}

Table 3: Some determined chemical compounds in untreated and treated AFW

\begin{tabular}{l|ccc}
\hline Samples & Tannins $(\%)$ & Hydrocyanides $(\mathrm{ppm})$ & Phytate $(\mathrm{mol} / \mathrm{kg})$ \\
\hline Raw AFW meal & $16.50 \pm 0.26$ & $4.10 \pm 0.17$ & $5.05 \pm 0.28$ \\
Fermented AFW meal & $13.40 \pm 0.24$ & $1.70 \pm 0.02$ & $2.53 \pm 0.06$ \\
AFW meal + NX & $13.20 \pm 0.36$ & $1.60 \pm 0.06$ & $2.40 \pm 0.07$ \\
AFW meal + R-G & $12.90 \pm 0.15$ & $1.52 \pm 0.01$ & $2.20 \pm 0.1$ \\
AFW meal + ME & $11.00 \pm 0.32$ & $1.40 \pm 0.1$ & $1.90 \pm 0.05$ \\
\hline
\end{tabular}


Table 4: Performance of cockerels fed raw and treated AFW supplemented with enzymes.

\begin{tabular}{|c|c|c|c|c|c|c|}
\hline \multirow[b]{2}{*}{ Parameters } & \multicolumn{6}{|c|}{ Diets } \\
\hline & 1 & 2 & 3 & 4 & 5 & SEM \\
\hline $\begin{array}{l}\text { Average feed intake } \\
(\mathrm{g} / \mathrm{b} / \mathrm{d})\end{array}$ & $82.14^{\mathrm{a}}$ & $16.67^{b}$ & $121.19^{c}$ & $133.33^{d}$ & $115.24^{\mathrm{e}}$ & 1.40 \\
\hline $\begin{array}{l}\text { Body weight gain } \\
(\mathrm{g} / \mathrm{b} / \mathrm{d})\end{array}$ & $20.83^{\mathrm{a}}$ & $10.12^{\mathrm{b}}$ & $17.26^{\mathrm{c}}$ & $17.98^{\mathrm{c}}$ & $17.26^{\mathrm{c}}$ & 3.70 \\
\hline $\begin{array}{l}\text { Feed conversion ratio } \\
(\mathrm{G} / \mathrm{F})\end{array}$ & $0.14^{\mathrm{a}}$ & $0.06^{\mathrm{b}}$ & $0.25^{\mathrm{b}}$ & $0.24^{\mathrm{c}}$ & $0.24^{\mathrm{c}}$ & 0.22 \\
\hline Survival (\%) & 100 & 37.5 & 95.30 & 95.70 & 96.50 & \\
\hline
\end{tabular}

Table 5: Composition of experimental diets (\%)

\begin{tabular}{l|lllll}
\hline & \multicolumn{5}{c}{ Diets } \\
Ingredients & 1 & 2 & 3 & 4 & 5 \\
\hline Maize & 60.00 & - & - & - & - \\
AFW & - & 60.00 & 60.00 & 60.00 & 60.00 \\
Nutrase xyla (NX) & - & - & 0.10 & - & - \\
Roxagyme-G (R-G) & - & - & - & 0.10 & - \\
Multiple enzymes (ME) & - & - & - & - & 0.10 \\
Soybean meal & 35.00 & 35.00 & 35.00 & 35.00 & 35.00 \\
DL-methionine & 0.50 & 0.50 & 0.50 & 0.50 & 0.50 \\
Mineral-vitamin premix* & 0.50 & 0.50 & 0.50 & 0.50 & 0.50 \\
Salt & 1.00 & 1.00 & 1.00 & 1.00 & 1.00 \\
Bone meal & 2.50 & 2.50 & 2.50 & 2.50 & 2.50 \\
Oyster shell & 0.50 & 0.50 & 0.50 & 0.50 & 0.50 \\
\hline Total & 100 & 100 & 100 & 100 & 100 \\
\hline *Mineral-vitamin premix: Provides per kg diet, 8000IU vitamin A; 1200 IU vitamin D3; 3.0 IU \\
vitamin E; 2mg vitamin K; 3mg riboflavin; 10mg nicotinic acid; 150mg panthothenic acid; \\
900mg choline; 0.25mg biotin; 125mg anti-oxidant (santoquin); 0.08mg cabalamin; $1.5 m g$ \\
folic acid; 80mg manganese; 50mg zinc; 2mg copper; 0.1mg selenium; 25mg iron and 0.2mg \\
cobalt.
\end{tabular}

fiber fractions. The tannin, hydrocyanide and phytate contents showed a progressive reduction in quantity following the different treatment methods.

Table 4 shows result of the performance of cockerels receiving treated and untreated AFW based diets supplemented or un-supplemented with enzymes. Treatments improved the nutritional value of $\mathrm{AFW}$ such that results obtained on performance indices, feed intake, body weight gain, feed conversion ratio and survival rate on treated and enzyme supplemented AFW diets were better than even the corresponding results gotten on the control diet $(\mathrm{p}<0.05)$. On the other hand, untreated/raw $\mathrm{AFW}$ in diet resulted to poor performance on all the parameters studied and caused high mortality of the birds $(\mathrm{p}<0.05)$.

\section{DICUSSION}

The proximate composition of AFW showed that the fruit waste contained essential nutrients, carbohydrate, protein, fat, fiber, mineral matter/ash. The analyses also showed that the nutrients content of the fruit waste increased as the raw $\mathrm{AFW}$ is processed. Increment in nutritive value following treatment of the fruit waste is of nutritional advantage to animals for feeding purpose. This is especially true since without treatment, the phytotoxins, tannins, hydrocyanides, phytic acid, oxalate and other anti-nutritional factors like the high fiber in the 
fruit may prevent the use of the available nutrients by the fed animal ${ }^{3,4}$

Determination of total fiber and its fractions (NDF, NDS, ADF, ADL) revealed that AFW is very high in fiber and its fractions. The fiber content seemed to diminish with treatments of the fruit waste. The high fiber content of the fruit waste could be a useful nutrient in nonruminant nutrition since this class of animals depends on certain level of high dietary fiber for optimal performance. Treatment of the fruit waste by enzymes and lactic fermentation, the methods which serve to degrade high fiber content and make it a useful nutrient besides detoxification is essential to make possible the use of AFW in feeding of monogastric animals that are unable to digest high dietary fiber ${ }^{12,13}$.

The chemical composition data on AFW indicated that the fruit waste obtained in this region (Ilorin metropolis) contains high concentration of tannins, hydrocyanides, phytic acid and the other un-quantified toxins like the oxalates. The concentration of the chemical compounds appeared to reduce with treatment and enzyme supplementation. The reduction suggests that for AFW to be useful as an alternative feedstuff for both ruminant and nonruminant animals, it must be given adequate treatments to eliminate or reduce the adverse effects of the toxins and the other anti-nutritional factors.

The bioassay of treated and untreated AFW using day-old cockerels as test animal models showed that statistical significant differences existed in daily feed consumption, growth rate, feed efficiency and mortality rate. The performance of birds on treated and enzyme supplemented AFW meal diets was highly improved even better than that on the standard diet. However, ingestion of untreated and unsupplemented AFW meal in diet elicited poor performance hence the raw AFW contained high anti-nutritional factors, toxins and high fiber. Result obtained on performance in this study is in agreement with past reports ${ }^{3,4}$ that intake of raw or unprocessed almond fruit by-product might prevent the utilization of nutrients therein due to the presence of anti-nutritional factors.
It was concluded that the nutritional potentials of AFW could be useful to animals when the fruit waste is given adequate treatments to eliminate the deleterious effects of the anti-nutritional factors

\section{REFERENCES}

1. Chyau, C. C., Ko, P. T., Mau, J. L. and Ka, M. D. (2000) Antioxidant activities of Terminalia catappa L. leaf extract. Dept. of Food Nutrition, Hung-Kuang Institute of technology, Tachung 433, Taiwan, ROC

2. Adeoti, A. T. (1998) Lipids seeds (Prunus amygdalus) physicochemical properties and their effects on the growth of rats. Unpublished B. Sc. Thesis, Biochemistry Dept., University of Ibadan, Ibadan, Nigeria.

3. Kochhar, S. L. (1986) In: Economic botany in the tropical countries, S. L. Kochhar (Ed), New Delhi, Maccy Publishing Co. India.

4. Jeremiah, F. A. (1992) Chemical evaluation and nutritional quality of almond fruits, In: Economic Botany in the Tropics. New Delhi, McMillan Publishing Company, India.

5. Annongu, A. A., ter Meulen, U., Atteh, J. O. and Apata, D. F. (1996) Toxicological assessment of native and industrial fermented sheabutter cake in nutrition of broilers. Arch. Gefluegelk. 60: 221-226.

6. AOAC (1990) Official Methods of Analysis, $15^{\text {th }}$ edition; Association of Official Analytical Chemists, Washington D. C.

7. Goering, H. K. and Van Soest, P. J. (1970) Forage fiber analysis, apparatus, reagents, procedures and some applications. Pages 1-20, Agricultural Handbook No 379, Agricultural research service, U. S. Dept. Agric. Washington D. C.

8. Joslyn, M. A. (1970) Methods in food analysis, Academic press, London, p 845.

9. Wheeler and Ferrel (1971) A method for phytic acid determination in wheat fractions. Cereal Chem. 48: 312-316.

10. Steel, R. G. O. and Torrie, J. H. (1980) Principles and Procedures of Statistics, Biometrical Approach, $2^{\text {nd }}$ edition, Mcgraw Hill Publishers.

11. Duncan, D. B. (1955) Multiple Range and Multiple F Test. Biometrics 11:1-42.

12. Walter, E.; Collins, E.; Philip, R. and Goodrich, M. W. (1984) In: Understanding 
Agricultural Waste Recycling. Technical Reviews.

13. Campbell, W. and Bedford, G. (1992)

Research on a new generation of enzymes for animal feeds. Proceedings of the European symposium on feed enzymes, Noord-Wijerhout, The Netherlands. 